\title{
Overexpressed p32 localized in the endoplasmic reticulum and mitochondria negatively regulates calcium-dependent endothelial nitric oxide synthase activity
}

\author{
KWANHOON CHOI ${ }^{1 *}$, BON-HYEOCK KOO ${ }^{2 *}$, BYEONG JUN YOON $^{2}$, MINKYO JUNG $^{3}$, \\ HYE YOUNG YUN ${ }^{1}$, BYUNG HWA JEON ${ }^{4}$, MOO-HO WON ${ }^{5}$, YOUNG-MYEONG KIM ${ }^{6}$, \\ JI YOUNG MUN ${ }^{3}$, HYUN KYO LIM ${ }^{1 *}$ and SUNGWOO RYOO ${ }^{2 *}$
}

\author{
${ }^{1}$ Department of Anesthesiology and Pain Medicine, Yonsei University Wonju College of Medicine, Wonju, \\ Gangwon 26426; ${ }^{2}$ Department of Biological Sciences, Kangwon National University, Chuncheon, Gangwon 24341; \\ ${ }^{3}$ Department of Neural Circuits Research, Korea Brain Research Institute, Dong, Daegu 41068; \\ ${ }^{4}$ Department of Physiology, School of Medicine, Chungnam National University, Daejeon 34134; \\ Departments of ${ }^{5}$ Neurobiology and ${ }^{6}$ Molecular and Cellular Biochemistry, \\ Kangwon National University, Chuncheon, Gangwon 24341, Republic of Korea
}

Received March 3, 2020; Accepted May 14, 2020

DOI: $10.3892 / \mathrm{mmr} .2020 .11307$

\begin{abstract}
The p32 protein plays a crucial role in the regulation of cytosolic $\mathrm{Ca}^{2+}$ concentrations $([\mathrm{Ca} 2+] \mathrm{c})$ that contributes to the $\mathrm{Ca}^{2+}$-dependent signaling cascade. Using an adenovirus and plasmid p32-overexpression system, the aim of the study was to evaluate the role of $\mathrm{p} 32$ in the regulation of $\left[\mathrm{Ca}^{2+}\right]$ and its potential associated with $\mathrm{Ca}^{2+}$-dependent endothelial nitric oxide synthase (eNOS) activation in endothelial cells. Using electron and confocal microscopic analysis, p32 overexpression was observed to be localized to mitochondria and the endoplasmic reticulum and played an important role in $\mathrm{Ca}^{2+}$ translocation, resulting in increased $\left[\mathrm{Ca}^{2+}\right]$ in these organelles and reducing cytosolic $\left[\mathrm{Ca}^{2+}\right]\left(\left[\mathrm{Ca}^{2+}\right] \mathrm{c}\right)$. This decreased $\left[\mathrm{Ca}^{2+}\right] \mathrm{c}$ following p32 overexpression attenuated the $\mathrm{Ca}^{2+}$-dependent signaling cascade of calcium/calmodulin dependent protein kinase II (CaMKII)/AKT/eNOS phosphorylation. Moreover, in aortic endothelia of wild-type mice intravenously administered adenovirus encoding the $\mathrm{p} 32$ gene, increased p 32 levels reduced
\end{abstract}

Correspondence to: Professor Sungwoo Ryoo, Department of Biological Sciences, Kangwon National University, 1 Kangwondae-gil, Chuncheon, Gangwon 24341, Republic of Korea

E-mail: ryoosw08@kangwon.ac.kr

Professor Hyun Kyo Lim, Department of Anesthesiology and Pain Medicine, Yonsei University Wonju College of Medicine, 20 Ilsanro, Wonju, Gangwon 26426, Republic of Korea

E-mail: hyunkyolim@yonsei.ac.kr

*Contributed equally

Key words: p32, calcium concentration, endoplasmic reticulum, mitochondria, endothelial nitric oxide synthase
NO production and accelerated reactive oxygen species (ROS) generation. In a vascular tension assay, p32 overexpression decreased acetylcholine (Ach)-induced vasorelaxation and augmented phenylephrine (PE)-dependent vasoconstriction. Notably, decreased levels of arginase II (ArgII) protein using siArgII were associated with downregulation of overexpressed p32 protein, which contributed to CaMKII-dependent eNOS phosphorylation at Ser1177. These results indicated that increased protein levels of p32 caused endothelial dysfunction through attenuation of the $\mathrm{Ca}^{2+}$-dependent signaling cascade and that ArgII protein participated in the stability of p32. Therefore, p32 may be a novel target for the treatment of vascular diseases associated with endothelial disorders.

\section{Introduction}

The p32 protein, also known as hyaluronan-binding protein 1, is usually localized to the mitochondria (1). However, p32 also acts as a cell surface receptor for globular head-domain complement 1q (2). p32 was originally recognized in the nucleus as a pre-mRNA splicing factor SF2-binding protein (3) and reported to be targeted to the Golgi apparatus (4). Exogenously epitope-tagged p32 at the $\mathrm{N}$-terminus can be redirected to the endoplasmic reticulum (ER) and cell surface (5). Functional studies have revealed that $\mathrm{p} 32$ is required for the induction of mitochondria-dependent cell death $(6,7)$ and p32 knockdown causes a metabolic shift from oxidative phosphorylation to aerobic glycolysis, which is poorly tumorigenic (8). In addition, p32 protein contributes to the morphology of the mitochondria and ER, as well as cellular metabolism and stress responses (9). Several potential p32 ligands have been identified. The p32 protein interacts with $\alpha 1 \mathrm{~B}$ - and $\alpha 1 \mathrm{D}$-adrenoreceptors, which control expression and cellular localization (10).p32 has also been revealed to interact with protein kinase $\mathrm{C}(\mathrm{PKC}) \mu$, a regulator of kinase activity and intracellular compartmentalization (11). 
Moreover, the p32 protein can interact with nuclear components such as the lamin B receptor, as a linker between the nuclear membrane and intranuclear substructures (12). p32 additionally binds to components of the extracellular matrix, hyaluronic acid (13) and vitronectin (14). It is also involved in cell adhesion and motility, viral proteins, HIV Tat (15), and EBV EBNA-1 (16), and exerts augmented transcriptional activation of viral proteins, bacterial surface protein, and InlB, which are necessary for bacterial invasion into mammalian cells (17).

Although endothelial nitric oxide synthase (eNOS) activity is regulated by extracellular signals, subcellular localization, and protein-protein interactions, $\mathrm{Ca}^{2+}$ mainly contributes to modulation of eNOS activity in these regulations. Activated $\mathrm{Ca}^{2+}$-bound calmodulin $\left(\mathrm{Ca}^{2+} / \mathrm{CaM}\right)$ from increased cytosolic $\mathrm{Ca}^{2+}\left(\left[\mathrm{Ca}^{2+}\right] \mathrm{c}\right)$ levels binds to the canonical CaM-binding domain in eNOS, which promotes the alignment of the oxygenase and reductase domains of eNOS and prevents eNOS Thr495 phosphorylation. $\mathrm{Ca}^{2+} / \mathrm{CaM}$ also activates $\mathrm{Ca}^{2+} /$ calmodulin-dependent protein kinase II (CaMKII), which participates in the phosphorylation of eNOS Ser1177 to increase NO release $(18,19)$. Intracellular $\mathrm{Ca}^{2+}$ can be transported and stored in the ER, and mitochondria. $\mathrm{Ca}^{2+}$ uptake by these organelles controls cellular $\mathrm{Ca}^{2+}$ homeostasis, regulates the oxidative phosphorylation rate and ATP synthesis, and attenuates transient $\left[\mathrm{Ca}^{2+}\right] \mathrm{c}(20)$.

Our previous study reported that arginase II participates in the $\mathrm{Ca}^{2+} / \mathrm{CaMKII} / \mathrm{eNOS}$ signaling cascade by $\mathrm{p} 32$-dependent regulation of $\left[\mathrm{Ca}^{2+}\right] \mathrm{c}(21)$. Downregulation of arginase II protein using small interfering (si)RNA and genetic deletion was associated with reduction of $\mathrm{p} 32$ protein levels, which resulted in increased $\left[\mathrm{Ca}^{2+}\right] \mathrm{c}$ and eNOS activation (21). Therefore, the present study investigated the target organelles of overexpressed p32 and determined whether the p32 involved in the regulation of $\left[\mathrm{Ca}^{2+}\right]$ was associated with $\mathrm{Ca}^{2+}$-dependent eNOS activation.

\section{Materials and methods}

Materials. NG-nitro-L-arginine methyl ester (L-NAME) and manganese (III) tetrakis (4-benzoic acid) porphyrin chloride (MnTBAP) were purchased from Calbiochem; Merck KGaA. Anti-sera against eNOS, phospho-eNOS (Ser1177 and Thr495), phospho-CaMKII, phospho-AKT (Ser473) and pan-actin were obtained from BD Biosciences, and antiserum to p32 was obatined from Abcam. The siRNA against arginase II (siArgII; cat. no. sc-29729) and scrambled RNA (scm; cat. no. sc-37007) were purchased from Santa Cruz Biotechnology, Inc. All other chemicals were obtained from Sigma-Aldrich, Merck KGaA, unless otherwise stated.

Cell culture and animals. Human umbilical vein endothelial cells (HUVECs) were purchased from Thermo Fisher Scientific, Inc. and maintained $\left(37^{\circ} \mathrm{C} ; 5 \% \mathrm{CO}_{2}\right)$ in Medium 200 containing low serum growth $(5 \%)$ supplement according to the supplier's instructions (Thermo Fisher Scientific, Inc.). Human epithelial cervical carcinoma (HeLa) and 293A cells were purchased from the American Type Culture Collection and maintained in DMEM (Thermo Fisher Scientific, Inc.) with 10\% FBS (Thermo Fisher Scientific, Inc.). Male C57BL/6J wild-type (WT; 21 mice; weight, 24 \pm 1.2 g; Daehan Biolink, Co., Ltd.) were obtained at 10 weeks of age and fed a normal diet. Mice were housed on $12 \mathrm{~h}$ dark/light cycle and had free access to food and water. Temperature and humidity were $24.2 \pm 1.5^{\circ} \mathrm{C}$ and $51.2 \pm 3.9 \%$, respectively. This study adhered to the Guide for the Care and Use of Laboratory Animals and was approved by the Institutional Review Board of Kangwon National University.

siRNA treatment and knockdown of mitochondrial p32. For siRNA transfection, HUVECs were incubated in starvation medium (DMEM plus 5\% FBS and penicillin and streptomycin $50 \mathrm{U} / \mathrm{ml}$ ) containing siRNA against p32 (sip32; $100 \mathrm{nmol} / \mathrm{l}$; 5'-TGTCTCCGTCGGTGTGCAGC-Cy5- 3'), scramble siRNA (100 nmol/1; 5'-GCTGCACACCGACGGAGACA-Cy5-3') or no oligonucleotide for $24 \mathrm{~h}$ without a reagent. siRNA against ArgII mRNA (siArgII; $100 \mathrm{nmol} / \mathrm{l}$ ) were transfected using the same method.

Electron microscopy (EM). The p32 gene was cloned into the AfII and BamHI restriction sites of the pcDNA3 connexin43-GFP-APEX2 plasmid (Addgene) for EM analysis. HeLa cells were grown on a gridded glass-bottom dish (MatTek Corporation). The day after seeding the cells (50\% confluence), the p32-APEX2 plasmid (1 $\mu \mathrm{g}$ DNA/60 mm dish) construct was transfected into HeLa cells with Lipofectamine ${ }^{\circledR} 3000$ (Thermo Fisher Scientific, Inc.). After $16-24 \mathrm{~h}$, the cells were fixed on ice using cold $1.5 \mathrm{ml}$ of fixation solution (1\% glutaraldehyde and $1 \%$ paraformaldehyde in $0.15 \mathrm{M}$ sodium cacodylate solution, $\mathrm{pH} 7.0$ ) for $30 \mathrm{~min}$. All subsequent studies were performed using pre-chilled buffers and reagents. Fixed cells were washed with $0.15 \mathrm{mM}$ cold sodium cacodylate buffer three times and then treated for $5 \mathrm{~min}$ with buffer containing $50 \mathrm{mM}$ glycine to quench the unreacted glutaraldehyde on ice. Staining using 3,3-diaminobenzidine (DAB) was initiated by adding freshly diluted $1 \mathrm{mg} / \mathrm{ml} \mathrm{DAB}$ (Sigma-Aldrich; Merck KGaA) from a stock $(10 \mathrm{mg} / \mathrm{ml})$ dissolved in $0.1 \mathrm{M} \mathrm{HCl}$ and $10 \mathrm{mM} \mathrm{H}_{2} \mathrm{O}_{2}$ in phosphate-buffered saline. After $30 \mathrm{~min}$ on ice, the reaction was stopped by removing the DAB solution, and the cells were washed with $0.15 \mathrm{M}$ cold sodium cacodylate buffer three times on ice. Post-fixation was performed using $2 \%$ (w/v) osmium tetroxide $\left(\mathrm{O}_{\mathrm{s}} \mathrm{O} 4\right)$ and $1.5 \%(\mathrm{w} / \mathrm{v})$ potassium ferrocyanide in $0.1 \mathrm{M}$ sodium cacodylate buffer for $1 \mathrm{~h}$ on ice. The cells were then rinsed three times for 10 min each in chilled distilled water, and dehydrated in a graded ethanol series $(50,60,70,80,90$ and 100\%) for 15 min each time, then they were infiltrated into EMbed-812 (Electron Microscopy Sciences) using 1:3 (v/v), 1:1 (v/v), and $3: 1(\mathrm{v} / \mathrm{v})$ resin and anhydrous ethanol for $1 \mathrm{~h}$. The samples were embedded with the $100 \%$ resin and incubated overnight at room temperature. The next day, the samples were filled again with $100 \%$ resin for $3 \mathrm{~h}$ at room temperature before transferring the sample to fresh resin, followed by polymerization at $60^{\circ} \mathrm{C}$ for $24 \mathrm{~h}$. The embedded cells were cut with a diamond knife into 50-nm sections using a ultramicrotome (Leica Microsystems, Inc.), and images were acquired by transmission electron microscopy (TEM; Tecnai G2; Thermo Fisher Scientific, Inc.) operating at $120 \mathrm{kV}$ (magnification, x20,000). The TEM data were acquired using the Brain Research Core Facilities at the Korea Brain Research Institute.

Mitochondrial fractionation. Cells and aortic segments were homogenized twice in subcellular fractionation buffer $(250 \mathrm{mM}$ sucrose, $20 \mathrm{mM}$ HEPES, pH 7.4, $10 \mathrm{mM} \mathrm{KCl,} 1.5 \mathrm{mM} \mathrm{MgCl}_{2}$, 
$1 \mathrm{mM}$ EDTA, $1 \mathrm{mM}$ EGTA, and protease inhibitors; Roche Diagnostics) for $3 \mathrm{~min}$ and centrifuged at $1,000 \mathrm{x} \mathrm{g}$ for $10 \mathrm{~min}$ at $4^{\circ} \mathrm{C}$ to remove cell debris and intact cells. The supernatants were then centrifuged at $21,000 \mathrm{x}$ g for $45 \mathrm{~min}$ at $4^{\circ} \mathrm{C}$. The cytosolic (supernatant) and mitochondrial (pellet) fractions containing $20 \mu \mathrm{g}$ protein were used for subsequent western blot analysis. The purity of the fractions was measured using western blotting for HSP60 and actin, respectively.

Western blot analysis. Proteins of cell lysates were dissolved in SDS-PAGE sample buffer (Tris- $\mathrm{HCl} 62.5 \mathrm{mM}, \mathrm{pH} 6.8$, SDS $2 \%$, glycerol $10 \%$, DTT $50 \mathrm{mM}$, bromophenolblue $0.01 \%$ ), then resolved by SDS-PAGE on $10 \%$ gels $(15 \mu \mathrm{g} / \mathrm{lane}$; determined by Bradford assay), transferred to PVDF and the membranes were blocked with 5\% skim milk (room temperature; $1 \mathrm{~h}$ ). Then, membranes were immunoblotted with a primary antibody $\left(4^{\circ} \mathrm{C} ; 12 \mathrm{~h} ; 1: 1,000\right)$ and the secondary antibody (room temperature; $2 \mathrm{~h} ; 1: 2,000)$. Antisera against eNOS (cat. no. 610297) and phospho-eNOS (Ser1177; cat. no. 612392; Thr495; cat. no. 612707) were acquired from BD Biosciences. p32 (cat. no. ab24733) antisera were obtained from Abcam. Akt (cat. no. 9272), phospho-Akt (Ser473; cat. no. 9271), CaMKII (cat. no. 3362), phospho-CaMKII (Thr286; cat. no. 12716) and pan-actin (cat. no. 4968) antisera were obtained from Cell Signaling Technology, Inc. Arginase II (cat. no. sc-271443) and HSP60 (cat. no. sc-13115) were purchased from Santa Cruz Biotechnology, Inc. Pan-actin was used as a reference protein. Horseradish peroxidase-conjugated antibody (Goat anti-mouse IgG, cat. no. G-21040; Goat anti-rabbit IgG, cat. no. G-21234; Thermo Fisher Scientific, Inc.) was detected using an enhanced ECL-based chemiluminescence system (Thermo Fisher Scientific, Inc.). Band intensities were analyzed using ImageJ software (Fiji; National Institutes of Health).

Immunofluorescence staining and imaging. Cells were washed with PBS, fixed at room temperature with $3.7 \%$ formaldehyde (Fisher Chemical Ltd.) for 15 min and permeabilized with 0.1\% Triton X-100 (Sigma-Aldrich; Merck KGaA). Samples were then washed three times with PBS, blocked at room temperature with $1 \%$ BSA (Sigma-Aldrich) for $\geq 1 \mathrm{~h}$ and incubated overnight with the indicated p32 primary antibody at $4^{\circ} \mathrm{C}$. Samples were rinsed with PBS three times before conjugation at room temperature for $1 \mathrm{~h}$ with the CY-5-conjugated secondary antibody (Thermo Fisher Scientific, Inc.; cat. no. A10524). Samples were imaged using epifluorescence microscopy (magnification, $x 10$ objective lens) equipped with the Metamorph program 7.6 (Molecular Devices LLC).

Preparation of p32-expressing adenovirus. The p32 plasmid, pCMV6-XL5, was purchased from OriGene Technologies, Inc. and subcloned into the BglII and $K p n I$ restriction sites of the pCMV-Tag1 plasmid. For virus generation, full-length p32 was cloned into the BamHI and XhoI sites of the pENTR-CMV vector that has attL sites for site-specific recombination using the Gateway Destination Vector system (Invitrogen; Thermo Fisher Scienfitic, Inc.). The site-specific recombination between the pENTR-CMV/p32 and the adenovirus vector, pAd/PL-DEST, was conducted using LR clonase II. WT Adp32 is an adenovirus encoding full-length human p32. The adenovirus was amplified in 293A cells and purified using an
Adeno- $\mathrm{X}^{\mathrm{TM}}$ purification kit (Takara Bio, Inc.) and the multiplicity of infection was determined using an Adeno- $\mathrm{X}^{\mathrm{TM}}$ titer kit (Takara Bio, Inc.). Adp32 was used to treat HUVECs at a concentration of $1 \times 10^{6} \mathrm{pfu} / \mathrm{ml}$. For in vivo mice experiments, the purified recombinant adenovirus containing $5 \times 10^{9}$ particles was injected in the tail vein of mice. Adenovirus only as an empty vector (Ad) was used as an adenoviral control.

Mitochondrial $\mathrm{Ca}^{2+}\left(\left[\mathrm{Ca}^{2+}\right] \mathrm{m}\right), \mathrm{ER} \mathrm{Ca}^{2+}\left(\left[\mathrm{Ca}^{2+}\right] \mathrm{ER}\right)$, and cytosolic $\mathrm{Ca}^{2+}\left(\left[\mathrm{Ca}^{2+}\right] c\right)$ measurements using confocal microscopy and flow cytometry. Direct assessment of $\left[\mathrm{Ca}^{2+}\right] \mathrm{m}$ content was peformed using an established loading procedure (21) with Rhod-2 acetoxymethyl (AM, Thermo Fisher Scientific, Inc.). Briefly, the cells were loaded with $2.5 \mu \mathrm{M}$ Rhod-2 AM at $37^{\circ} \mathrm{C}$ for $1 \mathrm{~h}$ in starvation medium (M199 and 1\% FBS plus penicillin and streptomycin $50 \mathrm{U} / \mathrm{ml}$ ). Subsequently, the cells were washed and incubated $\left(37^{\circ} \mathrm{C}\right.$ for $\left.30 \mathrm{~min}\right)$ in Tyrode's modified solution (150 mM NaCl, $4 \mathrm{mM} \mathrm{KCl,} 2 \mathrm{mM} \mathrm{CaCl}$, $2 \mathrm{mM} \mathrm{MgCl}$, $10 \mathrm{mM}$ HEPES, and $10 \mathrm{mM}$ glucose). For detection of Rhod-2 AM fluorescence, a 552-nm excitation (Ex) and a 581-nm emission (Em) filters were used. MitoTracker Green FM (Thermo Fisher Scientific, Inc.) was added to cells and incubated at $100 \mathrm{nM}$ for $1 \mathrm{~h}$ at $37^{\circ} \mathrm{C}$ and imaged at $490 \mathrm{~nm}$ exitation and $516 \mathrm{~nm}$ emission. To examine the $\left[\mathrm{Ca}^{2+}\right] \mathrm{ER}$, ER-tracker Red $(5 \mu \mathrm{M}$; $30 \mathrm{~min} ; 37^{\circ} \mathrm{C}$; Thermo Fisher Scientific, Inc.) and Fluo-5N AM $\left(5 \mu \mathrm{M} ; 1 \mathrm{~h} ; 37^{\circ} \mathrm{C}\right.$; Thermo Fisher Scientific, Inc.) were used to obtain images at wavelengths of $588 / 620 \mathrm{~nm}(\mathrm{Ex} / \mathrm{Em})$ and $488 / 530 \mathrm{~nm}(\mathrm{Ex} / \mathrm{Em})$, respectively. The $\left[\mathrm{Ca}^{2+}\right] \mathrm{c}$ was monitored using Fluo-4 AM (100 nM; 1 h; Thermo Fisher Scientific) at $494 \mathrm{~nm} \mathrm{Ex}$, and $506 \mathrm{~nm} \mathrm{Em}$. The intensity values were normalized according to the samples fluorescence values after subtraction of background using the Metamorph software 7.6 (Molecular Probes; Thermo Fisher Scientific, Inc.).

$\left[\mathrm{Ca}^{2+}\right] \mathrm{m},\left[\mathrm{Ca}^{2+}\right] \mathrm{ER}$, and $\left[\mathrm{Ca}^{2+}\right] \mathrm{c}$ were also determined using flow cytometry (FACSCalibur; BD Biosciences). The fluorescence intensity for each sample was determined using CellQuest software 5.1 (BD Biosciences). The $\mathrm{Ca}^{2+}$ level was determined by comparing the fold changes in the fluorescence intensities of treated cells relative to unstained control cells.

Measurement of nitric oxide $(\mathrm{NO})$ and reactive oxygen species (ROS). Aortic rings from 10-week-old male C57BL/6 WT mice were prepared for fluorescent probe labeling of superoxide [1 $\mu \mathrm{M}$ (final concentration); dihydroethidine (DHE); Abcam; cat. no. ab236206; ] and NO [5 $\mu \mathrm{M}$ (final concentration); 4-amino-5-methylamino-2',7'-difluorofluorescein diacetate (DAF-DA); cat. no. D23844; Thermo Fisher Scientific, Inc.). The fluorescent intensity was measured for 5 min with $30-\mathrm{sec}$ intervals at $37^{\circ} \mathrm{C}$. The NOS inhibitor, L-NAME $\left(10 \mu \mathrm{M} ; 37^{\circ} \mathrm{C}\right.$; $30 \mathrm{~min})$ blocked NO production and MnTBAP $\left(1 \mu \mathrm{M} ; 37^{\circ} \mathrm{C}\right.$; $30 \mathrm{~min})$, as a ROS scavenger, reduced DHE fluorescence intensity. Images were acquired using a BX51 epifluorescence microscope (magnification, x400; Olympus Corporation). Fluorescence intensity was measured as previously described (22) using the Metamorph software 7.6 (Molecular Probes; Thermo Fisher Scientific, Inc.).

Aortic vascular tension assay. Heparin was administered $1 \mathrm{~h}$ before mice were sacrificed. Mice were anesthetized using inhalant isoflurane (1\%), and the thoracic aorta from the aortic 

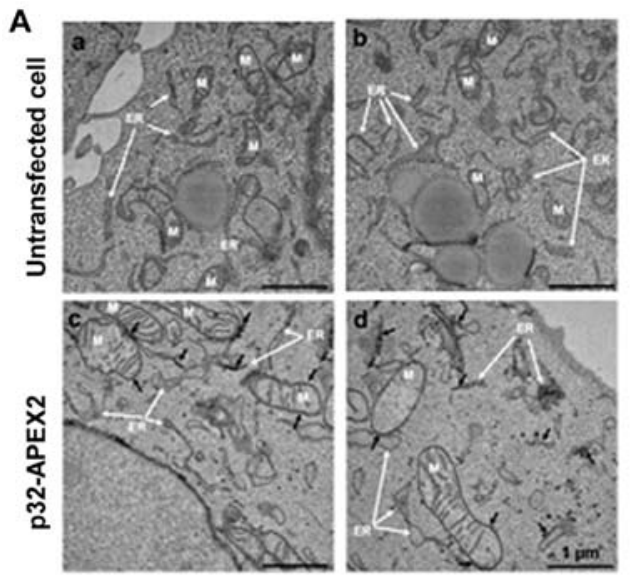

B
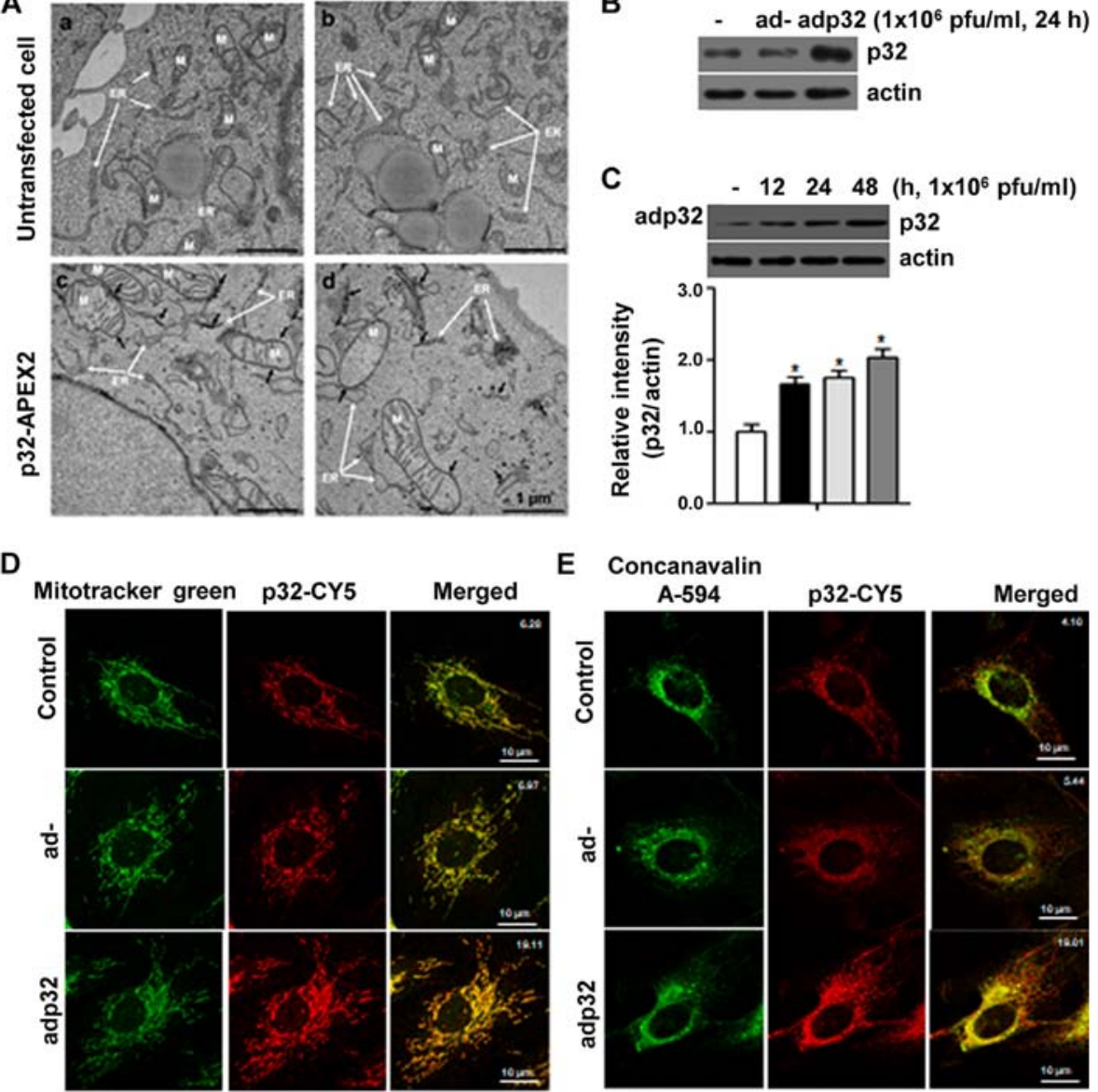

E Concanavalin
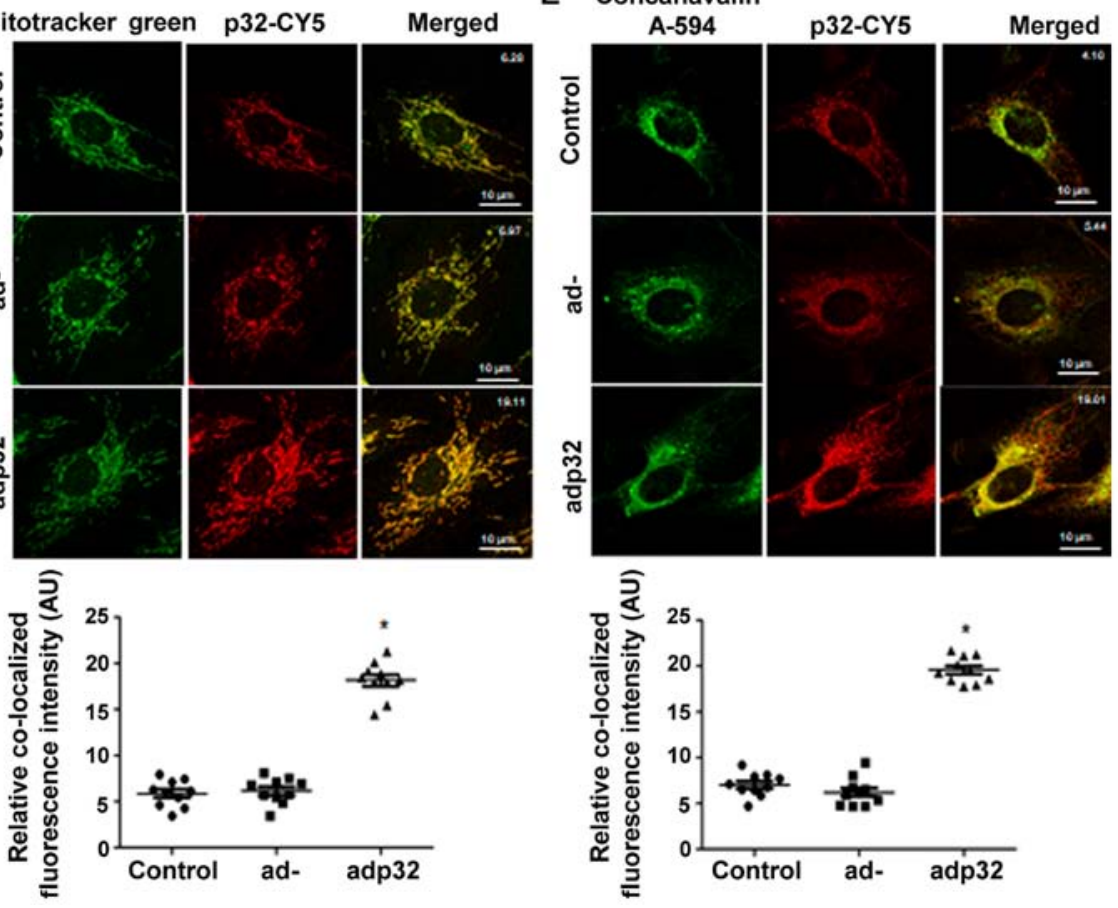

Figure 1. Overexpression of p32 in the ER and mitochondria. (A) Electron microscopic analysis of the p32 localization using tagged APEX2-generated 3,3-diaminobenzidine labeling pattern. Untransfected cells exhibited constant staining of mitochondria and the ER membrane (a and b). HeLa cells expressing the p32-APEX2 constructs exhibited clear densities in targeted areas. The APEX2 was targeted to the ER membrane and mitochondria membrane (black arrow, c and d). In adp32-treated HUVECs, (B) p32 protein levels were increased and (C) p32 expression was induced in a time-dependent manner. Confocal microscopic images of adp32-treated HUVECs indicated that overexpressed p32 localized to both (D) mitochondria and (E) ER. Mitotracker green and concanavalin A-594 were used as indicators of mitochondria and the ER, respectively. $n=3$. ${ }^{*} \mathrm{P}<0.05$, vs. untreated. HUVEC, human umbilical vein endothelial cell; ER, endoplasmic reticulum; ad, adenovirus; AU, arbitrary units.

root to the bifurcation of the iliac arteries was rapidly isolated and cut into $1.5 \mathrm{~mm}$ rings. The aortic rings were placed in ice-cold oxygenated Krebs-Ringer bicarbonate buffer $(118.3 \mathrm{mM}$ $\mathrm{NaCl}, 4.7 \mathrm{mM} \mathrm{KCl}, 1.2 \mathrm{mM} \mathrm{MgSO}$, $1.6 \mathrm{mM} \mathrm{CaCl}_{2}, 25 \mathrm{mM}$ $\mathrm{NaHCO}_{3}, 11.1 \mathrm{mM}$ glucose; $\mathrm{pH}$ 7.4) and suspended between two wire stirrups $(150 \mathrm{~mm}$ ) in a myograph (Multi Myograph System 620; Danish Myo Technology A/S) containing $10 \mathrm{ml}$ Krebs-Ringer $\left(95 \% \mathrm{O}_{2}, 5 \% \mathrm{CO}_{2}, \mathrm{pH} 7.4,37^{\circ} \mathrm{C}\right)$. One stirrup was connected to a three-dimensional micromanipulator, and the other to a force transducer. The aortic rings were passively stretched at $10 \mathrm{~min}$ intervals in increments of $100 \mathrm{mg}$ to reach the optimal tone $(600 \mathrm{mg})$. After the aortic rings were stretched to their optimal resting tone, the contractile response to $60 \mathrm{mM}$ $\mathrm{KCl}$ was determined. The response to a maximal dose of $\mathrm{KCl}$ was used to normalize the responses to agonist across vessel rings. Dose responses to the vasoconstrictor phenylephrine $\left(\mathrm{PE}, 10^{-9}-10^{-5} \mathrm{M}\right.$ ) were assessed, and responses to the vasodilators acetylcholine (Ach, $10^{-9}-10^{-5} \mathrm{M}$ ) and sodium nitroprusside $\left(\mathrm{SNP}, 10^{-10}-10^{-6} \mathrm{M}\right)$ were assessed after pre-constriction with PE $\left(10^{-5} \mathrm{M}\right)$. To further confirm the NO-dependent vasorelaxation activity, aortic rings were treated with $1 \mathrm{H}-[1,2,4]$ oxadiazolo[4,3-a]quinoxalin-1-one (ODQ, $\left.10^{-5} \mathrm{M}\right)$, a soluble guanylyl cyclase inhibitor.

Statistical analysis. Each graph represents cumulative data from three independent experiments performed at least in triplicate. Data were analyzed using one-way ANOVA with a Bonferroni post hoc test, or unpaired Student's t-test, or 
A

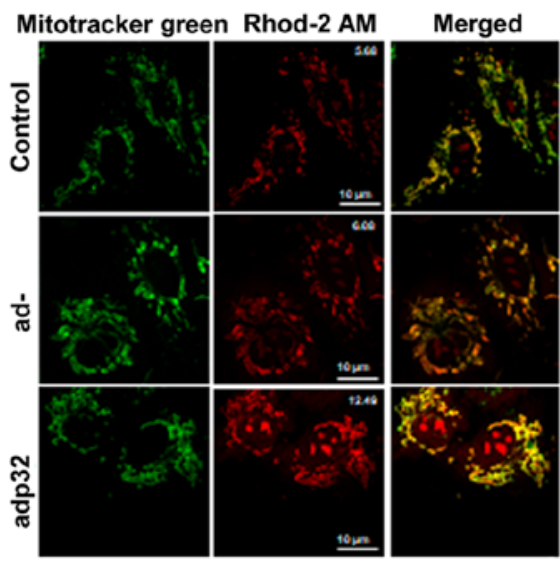

B

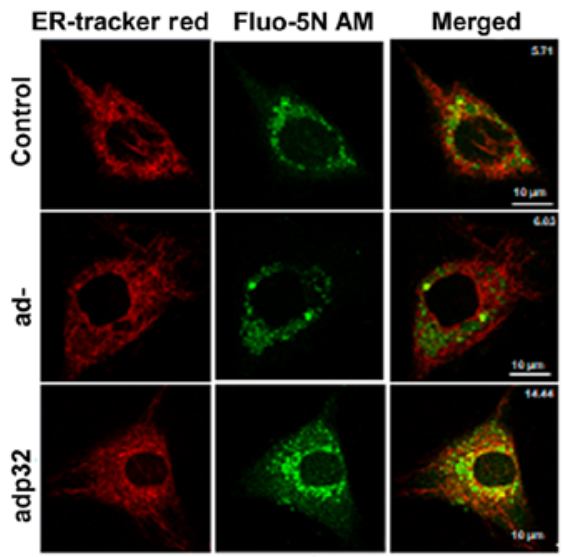

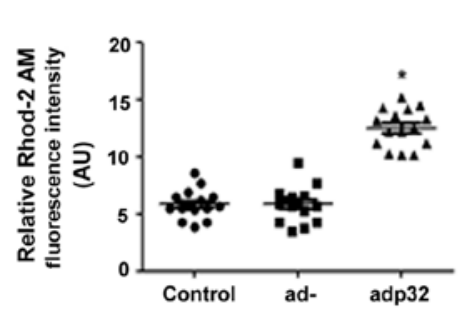
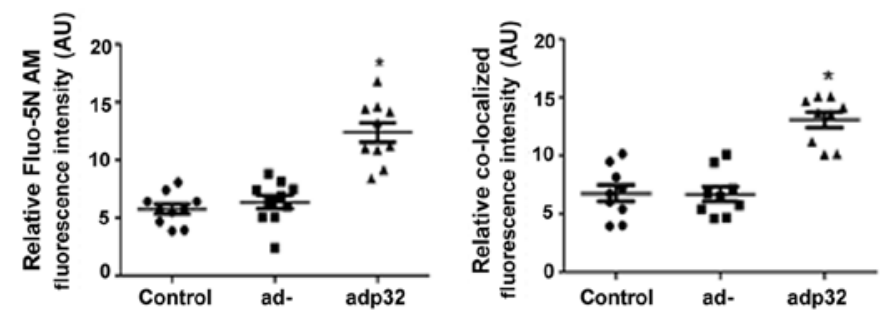

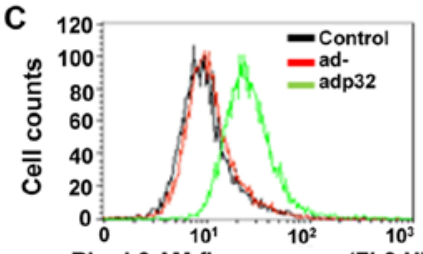

Rhod-2 AM fluorescence (FL2-H)

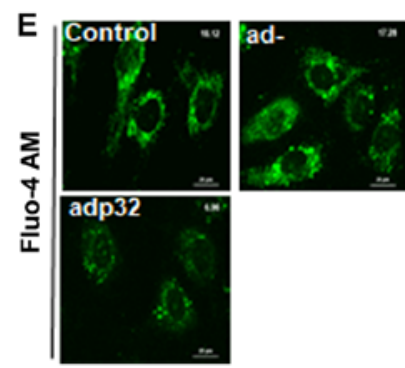

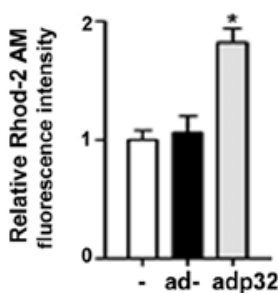

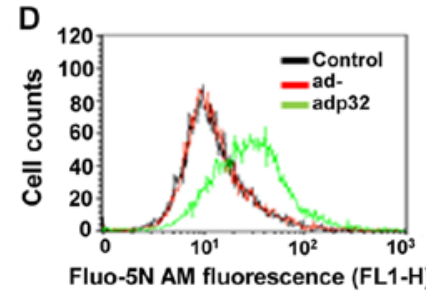

$\mathbf{F}$

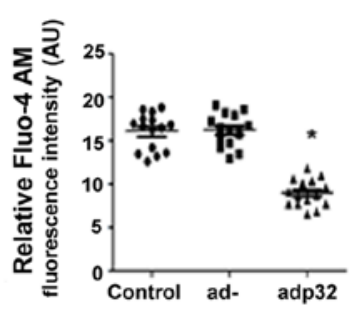

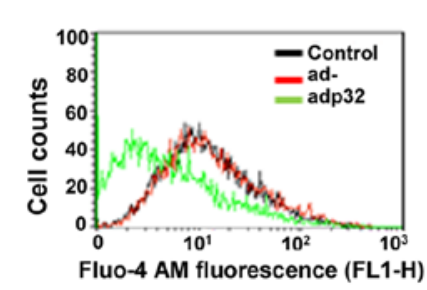
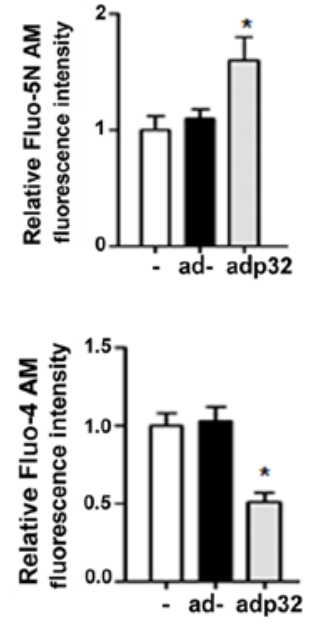

Figure 2. p32 overexpression increases $\left[\mathrm{Ca}^{2+}\right]$ in the ER and mitochondria. Adp32 infection induced increases in (A) $\left[\mathrm{Ca}^{2+}\right] \mathrm{m}$ and (B) $\left[\mathrm{Ca}^{2+}\right] \mathrm{ER}$ in microscopic images and in (C and D) FACS anaysis. Rhod-2 AM was used for detecting $\left[\mathrm{Ca}^{2+}\right] \mathrm{m}$ and Fluo-5N AM was used to measure $\left[\mathrm{Ca}^{2+}\right] \mathrm{ER}$. In microscopic images of $\left[\mathrm{Ca}^{2+}\right] \mathrm{ER}$, the fluorescent intensity of Fluo-5N AM was directly correlated with the co-localized fluorescent intensity of ER-tracker red and Fluo-5N AM (B, lower graph). Decreased $\left[\mathrm{Ca}^{2+}\right] \mathrm{c}$ was induced by adp32 infection (E) in microscopic images and (F) in FACS analysis. $n=3$. ${ }^{*} \mathrm{P}<0.05$, vs. ad. ER, endoplasmic reticulum; ad, adenovirus; $\left[\mathrm{Ca}^{2+}\right] \mathrm{m}$, mitochondrial calcium concentration; $\left[\mathrm{Ca}^{2+}\right] \mathrm{c}$, cytosolic calcium concentration; $\left[\mathrm{Ca}^{2+}\right] \mathrm{ER}, \mathrm{ER}$ calcium concentration; $\mathrm{AU}$, arbitrary units.

two-way ANOVA with Bonferroni correction test with Prism 5 software (GraphPad Software, Inc.). Data are presented either as the mean $\pm \mathrm{SEM}$, or mean $\pm \mathrm{SD}$ where two-way ANOVA was used. $\mathrm{P}<0.05$ was considered to indicate a statistically significant difference.

\section{Results}

p32 is targeted to the ER and mitochondria. To localize p32, EM analysis was carried out following overexpression of p32 in HeLa cells. p32 was localized to the ER, mitochondria and vesicles near to ER. In the untransfected cells (Fig. 1A-a and -b), the electron density of the mitochondria and the ER membrane was constant, but in the p32-APEX2 transfected cells (Fig. 1A-c and -d), strong electron density was found where DAB was precipitated, according to oxidation by the APEX2 enzyme. To further confirm these results, p32-expressing adenovirus (adp32) was generated and used to infect HUVECs. The protein amount of p32 was increased after adp32 infection (Fig. 1B) in a time-dependent manner (Fig. 1C). Using immunocytochemical analysis, p32 after adp32 treatment was targeted to the mitochondria (Fig. 1D) and ER (Fig. 1E). Mitotracker green and concanavalin A-594 were used to indicate mitochondria and ER, respectively, showing that overexpressed p32 was localized to the $\mathrm{Ca}^{2+}$ storage organelles (ER and mitochondria). Additionally, under normal physiological conditions, sip32 did not affect the change of $\left[\mathrm{Ca}^{2+}\right] \mathrm{ER}$, although $\left[\mathrm{Ca}^{2+}\right] \mathrm{m}$ was decreased (Fig. S1). This suggested that p32 was targeted to 
A

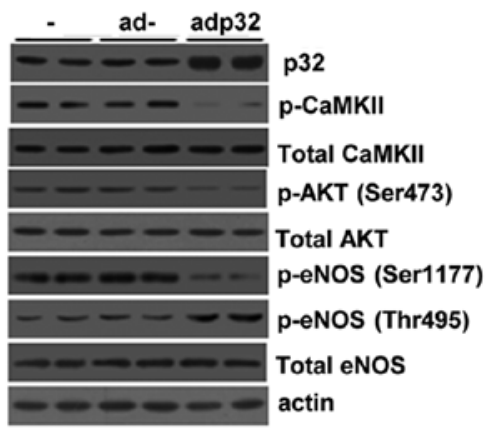

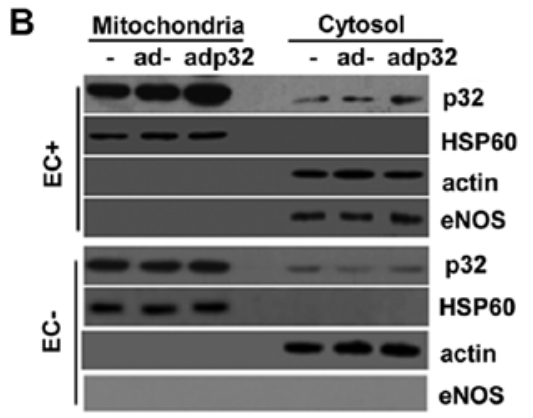
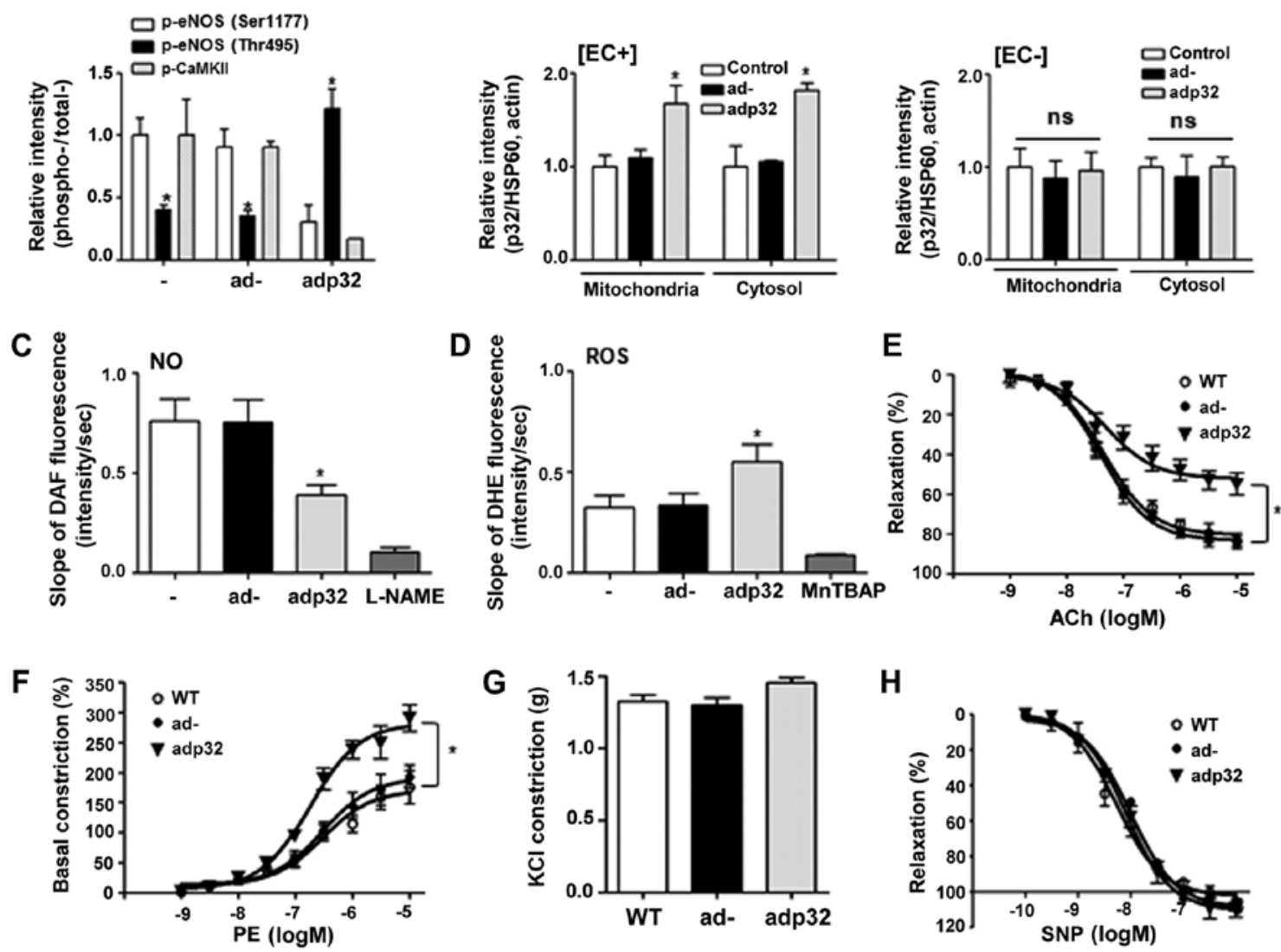

Figure 3. Adp32 infection impairs endothelial function attributing to reduced eNOS phosphorylation at Ser1177. (A) Mice (n=3) injected intravenously with $5 \times 10^{9} \mathrm{pfu}$ adp32 were sacrificed after $24 \mathrm{~h}$, and p32 expression was increased in aortas. Increased p32 expression decreased CaMKII/AKT/eNOS Ser1177 phosphorylations and increased eNOS phosphorylation at Thr495. Ad- had no effect on this signaling cascade. (B) The protein level of p32 was increased in the mitochondrial fraction of adp32-infected aortas, but the p32 protein level was not altered in the mitochondrial fraction of de-endothelialized vessels. (C) Adp32 infection attenuated NO production and (D) accelerated ROS generation. L-NAME and MnTBAP were used as a negative control. $\mathrm{n}=6$ aortas from three mice. Using the vascular tension assay, adp32-infected aortas had decreased responses to (E) Ach and (F) PE-dependent vasoconstrictive responses were accelerated. The $(\mathrm{G} \mathrm{KCl}$ response and $(\mathrm{H}) \mathrm{SNP}$ dose responses were the same in all groups. $\mathrm{n}=3$. " $\mathrm{P}<0.05$, vs. ad. eNOS, endothelial nitric oxide synthase; CaMKII, calcium/calmodulin dependent protein kinase II; NO, nitric oxide; ROS, reactive oxygen species; ad, adenovirus; Ach, acetylcholine, PE, phenylephrine; SNP, sodium nitroprusside.

mitochondria, and not to ER, under normal conditions without the presence of a membrane signal sequence.

p32 enhances $\mathrm{Ca}^{2+}$ flux from the cytosol to the ER and mitochondria, resulting in decreased $\left[\mathrm{Ca}^{2+}\right] c$. The effect of increased $\mathrm{p} 32$ levels on the $\mathrm{Ca}^{2+}$ concentration in target organelles was then evaluated by using fluorescent dye Rhod-2 AM as a mitochondrial $\mathrm{Ca}^{2+}$ indicator, and Fluo-5N AM as an $\mathrm{ER} \mathrm{Ca}^{2+}$ indicator. Both $\left[\mathrm{Ca}^{2+}\right] \mathrm{m}$ and $\left[\mathrm{Ca}^{2+}\right] \mathrm{ER}$ were significantly increased after adp32 treatment (Fig. 2A and B). The fluorescence intensities of Fluo-5N alone were analyzed and co-localization of Fluo-5N and ER-tracker red were observed from the microscopic images of adp32-infected HUVECs (Fig. 2B).
Using flow cytometry, Rhod-2 and Fluo-5N intensities were significantly increased following adp 32 transfection (Fig. 2C and D), indicating that increased $\mathrm{p} 32$ protein in both organelles caused an uptake of $\mathrm{Ca}^{2+}$. Whether adp32 changed $\left[\mathrm{Ca}^{2+}\right] \mathrm{c}$ was then tested using Fluo-4 AM. $\left[\mathrm{Ca}^{2+}\right] \mathrm{c}$ was decreased in adp32-treated HUVECs as observed using both microscopy (Fig. 2E) and flow cytometry (Fig. 2F). Altogether, these findings indicated that adp32-dependent $\mathrm{p} 32$ overexpression decreased $\left[\mathrm{Ca}^{2+}\right] \mathrm{c}$ by mediating $\mathrm{Ca}^{2+}$ uptake into the ER and mitochondria.

p32 overexpression attenuates $\mathrm{Ca}^{2+}$-dependent eNOS phosphorylation and impaired endothelial function. Because 


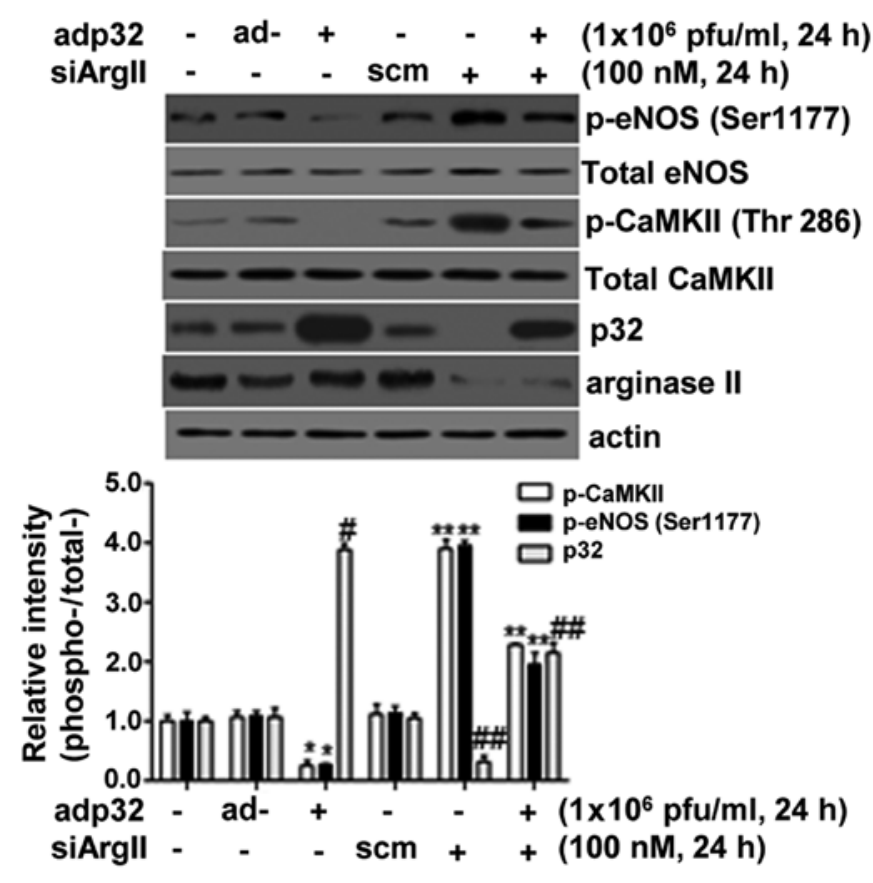

Figure 4. ArgII protein regulates the stability of p32 protein. SiArgII was simultaneously incubated with adp32 for $24 \mathrm{~h}$ in HUVECs followed by determination of CaMKII and eNOS phosphorylations. Decreases in arginase II protein levels by siArgII incubation reduced $\mathrm{p} 32$ protein levels, resulting in increased phosphorylations of CaMKII/AKT/eNOS Ser1177. $n=3 .{ }^{*} \mathrm{P}<0.05$ vs. ad; ${ }^{* *} \mathrm{P}<0.01$, vs. scm; ${ }^{\# \mathrm{P}}<0.01$ vs. ad; ${ }^{\# \#} \mathrm{P}<0.01$ vs. scm. HUVEC, human umbilical vein endothelial cell; ad, adenovirus; ArgII, arginase II; CaMKII, calcium/calmodulin dependent protein kinase II; eNOS, endothelial nitric oxide synthase; si, small interfering; scm, scramble.

$\left[\mathrm{Ca}^{2+}\right] \mathrm{c}$ plays an important role in the regulation of eNOS activity through CaMKII-dependent signaling cascade in endothelial cells (ECs) (21), the $\mathrm{Ca}^{2+}$-dependent signaling cascade associated with eNOS phosphorylation was next examined. p32 overexpression attenuated the signaling cascade of CaMKII/AKT/eNOS Ser1177 phosphorylations and increased eNOS Thr495 phosphorylation without any effect on the proteins levels (Fig. 3A). To determine the effect of adp32 on endothelial function, the adp32 vector was injected into WT mice. Aortic vessels were isolated from the sacrificed mice to confirm that the amount of p32 protein was predominantly overexpressed in ECs, but not smooth muscle cells (SMCs) (Fig. 3B). In aortic endothelia infected with adp32, NO production was significantly attenuated (Fig. 3C) and ROS generation was accelerated (Fig. 3D). Using the vascular tension assay, Ach-induced vasorelaxation responses were decreased (Fig. 3E), while PE-dependent dose responses were increased (Fig. 3F). Responses to $\mathrm{KCl}$ (Fig. 3G) and the NO donor SNP (Fig. 3H) remained similar across all groups.

Decreased ArgII protein levels restore adp32-dependent inactivation of eNOS. Because ArgII protein knockdown using siRNA decreases the levels of p32 protein in normal physiological conditions (21), the effect of siArgII on p32 overexpression following adp32 transfection was then evaluated. Notably, reduced ArgII protein levels after siArgII treatment resulted in decreased levels of p32 and increased CaMKII and eNOS phosphorylation in adp32-treated HUVECs (Fig. 4).
These results indicated that arginase II protein was involved in the regulation of $\mathrm{p} 32$ expression.

\section{Discussion}

In the present study, overexpressed p32 was preferentially localized to the ER and mitochondria, and played an important role in $\mathrm{Ca}^{2+}$ translocation that resulted in $\left[\mathrm{Ca}^{2+}\right] \mathrm{c}$ regulation. In addition, p32 overexpression decreased $\left[\mathrm{Ca}^{2+}\right] \mathrm{c}$, which, in turn attenuated the $\mathrm{Ca}^{2+}$-dependent signaling cascade involving CaMKII/AKT/eNOS phosphorylation. Using a vascular functional assay, it was demonstrated that increased p32 reduced NO production and accelerated ROS generation in aortic endothelia. This was accompanied by reduced Ach-induced vasorelaxation and augmented PE-dependent vasoconstriction. Notably, ArgII knockdown also led to p32 downregulation.

p32 is exclusively located in mitochondria, consistent with the mitochondrial targeting sequence (MTS) contained in its $73 \mathrm{~N}$-terminal amino acid sequence $(1,8)$. However, in the present study, Flag-p32 overexpression using ad and plasmid was localized to the ER and mitochondria as revealed in EM and confocal microscopy. These results are consistent with a previous study that reported that the addition of an epitope tag to the N-terminus of p32 blocked the MTS, resulting in redirection due to the net negative charge of the Flag tag or due to a spacing alteration within the N-terminus (5). Notably, as indicated by EM imaging, p32 overexpression was localized to the ER membrane, mitochondrial membrane, and vesicles. p32 targeting to the ER membrane can be explained by: i) A GFP-APEX2-dependent disturbance of p32 MTS; ii) alterations of protein interactions in the ER; iii) redirection attributed to ER stress; iv) possible membrane signals in $\mathrm{p} 32$; and v) signal sequences directed to the secretory pathway (23).

p32 is a multifunctionally and multicompartmentally (targted to various organelles) conserved eukaryotic protein. In our previous study (21), the binding ability of p32 to $\mathrm{Ca}^{2+}$ was assessed, demonstrating that spermine produced from arginase activity directly bound to p32 to facilitate $\mathrm{Ca}^{2+}$ release. Knockdown of p32 resulted in reduced intracellular ATP levels, restored endothelial function in ECs and decreased ROS generation in aortic vessels (21). p32 protein levels were upregulated in ECs (21) and SMCs (24) of $\mathrm{ApoE}^{-/-}$mice fed an high cholesterol diet (HCD), which was associated with the impairment of the intracellular $\mathrm{Ca}^{2+}$ signaling cascade. p32 in mitochondria also plays a key functional role in $\mathrm{Ca}^{2+}$ movement from the cytosol to mitochondria in ECs and SMCs $(21,24)$. p32 overexpression in mitochondria and the ER consistently increases in $\mathrm{Ca}^{2+}$ concentrations in both organelles, while and $\left[\mathrm{Ca}^{2+}\right] \mathrm{c}$ is reciprocally reduced. These results suggested that p32 itself functioned as a channel-like protein, and not as a component of the $\mathrm{Ca}^{2+}$ channel complex, based on the EM images, which localized it on the membrane, as well as measurements of $\mathrm{Ca}^{2+}$ concentrations in the p32-targeted ER. Because $\left[\mathrm{Ca}^{2+}\right] \mathrm{c}$ is an important regulator of eNOS in ECs (25), p32 overexpression induced decreases in $\left[\mathrm{Ca}^{2+}\right] \mathrm{c}$ that resulted in attenuated eNOS Ser1177 phosphorylation through the CaMKII/AKT signaling cascade, and enhanced eNOS Thr495 phosphorylation. These results correlated with endothelial NO production and reduced Ach-dependent vasorelaxation, 
and augmented PE-induced vasoconstriction. Therefore, p32 could represent a new therapeutic target for vascular disorders such as atherosclerosis in which NO production is interrupted and detrimental ROS generation is promoted by endothelial dysfunction.

ArgII is the principal extrahepatic isoform in human and mouse aortic ECs, and provides L-ornithine for the synthesis of polyamines associated with cell proliferation and differentiation $(26,27)$. ArgII is also induced by hypoxia, lipopolysaccharide, and tumor necrosis factor $\alpha$ (28-30), and increased ArgII activity in ECs has recently been linked to other disorders in animal models, including aging (31), ischemic reperfusion injury $(32,33)$, hypertension $(34,35)$, ballon injury (36) and atherosclerosis (22). Because p32 plays an essential role in the regulation of $\left[\mathrm{Ca}^{2+}\right] \mathrm{c}$, the stability of $\mathrm{p} 32$ is important for the maintenance of intracellular $\mathrm{Ca}^{2+}$ homeostasis (21). A novel mechanism can therefore be proposed, in which ArgII is associated with p32 stability. Consistent with this possibility, siRNA knockdown of ArgII resulted in decreased $\mathrm{p} 32$ protein.

In conclusion, p32 adenoviral overexpression predominantly localized to the mitochondria and ER membrane and accelerated $\mathrm{Ca}^{2+}$ movement into these organelles, which was associated with a decrease in $\left[\mathrm{Ca}^{2+}\right] \mathrm{c}$. p32 overexpression also decreased the $\mathrm{Ca}^{2+}$-dependent signaling cascade involved in eNOS activation and CaMKII/AKT/eNOS Ser1177 phosphorylation, and decreased NO production and increased the generation of ROS. Increased levels of p32 induced endothelial dysfunction and impaired Ach-stimulated vasorelaxation responses. Furthermore, the present study also suggests that ArgII protein plays an important role in the maintenance of p32 stability.

\section{Acknowledgements}

The authors would like to thank to Miss H.A. Kim (the Central Laboratory of Kangwon National University) for technical assistance with the instruments.

\section{Funding}

The present study was supported by The Basic Science Research Program of The National Research Foundation of Korea funded by The Ministry of Education, Science and Technology (grant nos. 2016M3A9B6903185 and 2018R1D1A1B07047959) and by a 2019 research grant (PoINT) from Kangwon National University program. Ji Young Mun and Minkyo Jung were supported by The Korea Brain Research Institute funded by The Ministry of Science and Information and Communications Technology (grant. no. 19-BR-01-08).

\section{Availability of data and materials}

The datasets used and/or analyzed during the current study are available from the corresponding author on reasonable request.

\section{Authors' contributions}

KC, BHK, HYY, BJY and MJ performed the experiments. BHJ, MHW and YMK analyzed the data and wrote the manuscript.
JYM, HKL and SR designed the study and wrote the manuscript. All authors read and approved the final manuscript.

\section{Ethics approval and consent to participate}

All experiments were performed with the approval of the Ethics Committee of Kangwon National University.

\section{Patient consent for publication}

Not applicable.

\section{Competing interests}

The authors declare that they have no competing interests.

\section{References}

1. Ghebrehiwet B, Lim BL, Peerschke EI, Willis AC and Reid KB: Isolation, cDNA cloning, and overexpression of a $33-\mathrm{kD}$ cell surface glycoprotein that binds to the globular 'heads' of C1q. J Exp Med 179: 1809-1821, 1994.

2. Krainer AR, Mayeda A, Kozak D and Binns G: Functional expression of cloned human splicing factor SF2: Homology to RNA-binding proteins, U1 70K, and Drosophila splicing regulators. Cell 66: 383-394, 1991.

3. Muta T, Kang D, Kitajima S, Fujiwara T and Hamasaki N: p32 protein, a splicing factor 2-associated protein, is localized in mitochondrial matrix and is functionally important in maintaining oxidative phosphorylation. J Biol Chem 272: 24363-24370, 1997.

4. Sengupta A, Banerjee B, Tyagi RK and Datta K: Golgi localization and dynamics of hyaluronan binding protein 1 (HABP1/p32/C1QBP) during the cell cycle. Cell Res 15: 183-186, 2005.

5. van Leeuwen $\mathrm{HC}$ and $\mathrm{O}$ 'Hare $\mathrm{P}$ : Retargeting of the mitochondrial protein $\mathrm{p} 32 / \mathrm{gC} 1 \mathrm{Q} r$ to a cytoplasmic compartment and the cell surface. J Cell Sci 114: 2115-2123, 2001.

6. Itahana $\mathrm{K}$ and Zhang Y: Mitochondrial p32 is a critical mediator of ARF-induced apoptosis. Cancer Cell 13: 542-553, 2008.

7. Sunayama J, Ando Y, Itoh N, Tomiyama A, Sakurada K, Sugiyama A, Kang D, Tashiro F, Gotoh Y, Kuchino Y, et al: Physical and functional interaction between $\mathrm{BH} 3$-only protein Hrk and mitochondrial pore-forming protein p32. Cell Death Differ 11: 771-781, 2004.

8. Fogal V, Richardson AD, Karmali PP, Scheffler IE, Smith JW and Ruoslahti E: Mitochondrial p32 protein is a critical regulator of tumor metabolism via maintenance of oxidative phosphorylation. Mol Cell Biol 30: 1303-1318, 2010.

9. Hu M, Crawford SA, Henstridge DC, Ng IH, Boey EJ, Xu Y, Febbraio MA, Jans DA and Bogoyevitch MA: p32 protein levels are integral to mitochondrial and endoplasmic reticulum morphology, cell metabolism and survival. Biochem J 453: 381-391, 2013.

10. Pupo AS and Minneman KP: Specific interactions between gC1qR and alpha1-adrenoceptor subtypes. J Recept Signal Transduct Res 23: 185-195, 2003.

11. Storz P, Hausser A, Link G, Dedio J, Ghebrehiwet B, Pfizenmaier K and Johannes FJ: Protein kinase $\mathrm{C}$ [micro] is regulated by the multifunctional chaperon protein $\mathrm{p} 32$. J Biol Chem 275: 24601-24607, 2000.

12. Simos G and Georgatos SD: The lamin B receptor-associated protein p34 shares sequence homology and antigenic determinants with the splicing factor 2-associated protein $\mathrm{p} 32$. FEBS Lett 346: 225-228, 1994.

13. Deb TB and Datta K: Molecular cloning of human fibroblast hyaluronic acid-binding protein confirms its identity with P-32, a protein co-purified with splicing factor SF2. Hyaluronic acid-binding protein as P-32 protein, co-purified with splicing factor SF2. J Biol Chem 271: 2206-2212, 1996.

14. Lim BL, Reid KB, Ghebrehiwet B, Peerschke EI, Leigh LA and Preissner KT: The binding protein for globular heads of complement C1q, gClqR. Functional expression and characterization as a novel vitronectin binding factor. J Biol Chem 271: 26739-26744, 1996. 
15. Yu L, Zhang Z, Loewenstein PM, Desai K, Tang Q, Mao D, Symington JS and Green M: Molecular cloning and characterization of a cellular protein that interacts with the human immunodeficiency virus type 1 Tat transactivator and encodes a strong transcriptional activation domain. J Virol 69: 3007-3016, 1995.

16. Wang Y, Finan JE, Middeldorp JM and Hayward SD: P32/TAP, a cellular protein that interacts with EBNA-1 of Epstein-Barr virus. Virology 236: 18-29, 1997.

17. Braun L, Ghebrehiwet B and Cossart P: gC1q-R/p32, a Clq-binding protein, is a receptor for the InlB invasion protein of Listeria monocytogenes. EMBO J 19: 1458-1466, 2000.

18. Fleming I, Fisslthaler B, Dimmeler S, Kemp BE and Busse R: Phosphorylation of $\mathrm{Thr}(495)$ regulates $\mathrm{Ca}(2+) / \mathrm{calmod}-$ ulin-dependent endothelial nitric oxide synthase activity. Circ Res 88: E68-E75, 2001.

19. Salerno JC, Harris DE, Irizarry K, Patel B, Morales AJ, Smith SM, Martasek P, Roman LJ, Masters BS, Jones CL, et al: An autoinhibitory control element defines calcium-regulated isoforms of nitric oxide synthase. J Biol Chem 272: 29769-29777, 1997.

20. Lobatón CD, Vay L, Hernández-Sanmiguel E, Santodomingo J, Moreno A, Montero M and Alvarez J: Modulation of mitochondrial $\mathrm{Ca}(2+)$ uptake by estrogen receptor agonists and antagonists. Br J Pharmacol 145: 862-871, 2005.

21. Koo BH, Hwang HM, Yi BG, Lim HK, Jeon BH, Hoe KL, Kwon YG, Won MH, Kim YM, Berkowitz DE, et al: Arginase II Contributes to the $\mathrm{Ca}^{2+} / \mathrm{CaMKII} / \mathrm{eNOS} \mathrm{Ax}$ is by Regulating $\mathrm{Ca}^{2+}$ Concentration Between the Cytosol and Mitochondria in a p32-Dependent Manner. J Am Heart Assoc 7: e009579, 2018.

22. Ryoo S, Gupta G, Benjo A, Lim HK, Camara A, Sikka G, Lim HK, Sohi J, Santhanam L, Soucy K, et al: Endothelial arginase II: A novel target for the treatment of atherosclerosis. Circ Res 102: 923-932, 2008.

23. Peerschke EI and Ghebrehiwet B: The contribution of $\mathrm{gClqR} / \mathrm{p} 33$ in infection and inflammation. Immunobiology 212: 333-342, 2007.

24. 24. Koo BH, Hong D, Hong HD, Lim HK, Hoe KL, Won M-H, Kim YM, Berkowitz DE and Ryoo S: Arginase II activity regulates cytosolic $\mathrm{Ca}(2+)$ level in a p32-dependent manner that contributes to $\mathrm{Ca}(2+)$-dependent vasoconstriction in native low-density lipoprotein-stimulated vascular smooth muscle cells. Exp Mol Med 51: 1-12, 2019.

25. Sessa WC: eNOS at a glance. J Cell Sci 117: 2427-2429, 2004

26. Ignarro LJ, Buga GM, Wei LH, Bauer PM, Wu G and del Soldato P: Role of the arginine-nitric oxide pathway in the regulation of vascular smooth muscle cell proliferation. Proc Natl Acad Sci USA 98: 4202-4208, 2001.
27. Li H, Meininger CJ, Hawker JR Jr, Haynes TE, Kepka-Lenhart D, Mistry SK, Morris SM Jr and Wu G: Regulatory role of arginase I and II in nitric oxide, polyamine, and proline syntheses in endothelial cells. Am J Physiol Endocrinol Metab 280: E75-E82, 2001.

28. Morris SM Jr, Kepka-Lenhart D and Chen LC: Differential regulation of arginases and inducible nitric oxide synthase in murine macrophage cells. Am J Physiol 275: E740-E747, 1998.

29. Louis CA, Reichner JS, Henry WL Jr, Mastrofrancesco B, Gotoh T, Mori M and Albina JE: Distinct arginase isoforms expressed in primary and transformed macrophages: Regulation by oxygen tension. Am J Physiol 274: R775-R782, 1998.

30. Collado B, Sánchez-Chapado M, Prieto JC and Carmena MJ: Hypoxia regulation of expression and angiogenic effects of vasoactive intestinal peptide (VIP) and VIP receptors in LNCaP prostate cancer cells. Mol Cell Endocrinol 249: 116-122, 2006.

31. Berkowitz DE, White R, Li D, Minhas KM, Cernetich A, Kim S, Burke S, Shoukas AA, Nyhan D, Champion HC, et al: Arginase reciprocally regulates nitric oxide synthase activity and contributes to endothelial dysfunction in aging blood vessels. Circulation 108: 2000-2006, 2003.

32. Hein TW, Zhang C, Wang W, Chang CI, Thengchaisri N and Kuo L: Ischemia-reperfusion selectively impairs nitric oxide-mediated dilation in coronary arterioles: Counteracting role of arginase. FASEB J 17: 2328-2330, 2003.

33. Jung C, Gonon AT, Sjöquist PO, Lundberg JO and Pernow J: Arginase inhibition mediates cardioprotection during ischaemia-reperfusion. Cardiovasc Res 85: 147-154, 2010.

34. Zhang C, Hein TW, Wang W, Miller MW, Fossum TW, McDonald MM, Humphrey JD and Kuo L: Upregulation of vascular arginase in hypertension decreases nitric oxide-mediated dilation of coronary arterioles. Hypertension 44: 935-943, 2004.

35. Johnson FK, Johnson RA, Peyton KJ and Durante W: Arginase inhibition restores arteriolar endothelial function in Dahl rats with salt-induced hypertension. Am J Physiol Regul Integr Comp Physiol 288: R1057-R1062, 2005.

36. Peyton KJ, Ensenat D, Azam MA, Keswani AN, Kannan S, Liu XM, Wang H, Tulis DA and Durante W: Arginase promotes neointima formation in rat injured carotid arteries. Arterioscler Thromb Vasc Biol 29: 488-494, 2009.

This work is licensed under a Creative Commons Attribution-NonCommercial-NoDerivatives 4.0 International (CC BY-NC-ND 4.0) License. 